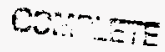

ENGINEERING CHANGE NOTICE

1. ECN $\therefore \div=2$

Page 1 of 2 Proj.

\begin{tabular}{|c|c|c|c|c|c|}
\hline \multirow{3}{*}{$\begin{array}{l}\text { 2. ECN Category } \\
\text { (mark one) } \\
\text { Supplenental } \\
\text { Direct Revision } \\
\text { Change ECN } \\
\text { Temporary } \\
\text { Standby } \\
\text { Supersedure } \\
\text { Cancel/Void }\end{array}$} & \multirow{3}{*}{$\begin{array}{r}{[]} \\
{[X]} \\
{[]} \\
{[]} \\
{[]} \\
{[]} \\
{[]}\end{array}$} & \multicolumn{2}{|c|}{$\begin{array}{l}\text { 3. Originator's Name, Organization, MSIN, } \\
\text { and Jelephone No. } \\
\text { Clarence Homi. Evaluation and } \\
\text { Planning. R2-12, } 373-1097\end{array}$} & $\begin{array}{l}\text { 3a. USQ Required? } \\
{[] \text { Yes }[X] \text { No }}\end{array}$ & $\begin{array}{l}\text { 4. Date } \\
05 / 09 / 96\end{array}$ \\
\hline & & \multicolumn{2}{|c|}{$\begin{array}{l}\text { 5. Project Title/No./Work order No. } \\
\text { Tank 241-S-110 }\end{array}$} & $\begin{array}{l}\text { 6. Bldg./5ys./Fac. No. } \\
241-5-110\end{array}$ & $\begin{array}{l}\text { 7. Approval Designator } \\
\text { N/A }\end{array}$ \\
\hline & & \multicolumn{2}{|c|}{$\begin{array}{l}\text { 8. Document Numbers Changed by this ECN } \\
\text { (includes sheet no. and rev.) } \\
\text { WHC-SD-WM-TP-205. Rev. 1-D }\end{array}$} & $\begin{array}{l}\text { 9. Related ECN No(s). } \\
\text { ECNs: } 609267 \\
609269,621339 \\
613660,623942 \\
\end{array}$ & $\begin{array}{l}\text { 10. Related PO No. } \\
\qquad N / A\end{array}$ \\
\hline \multirow{2}{*}{\multicolumn{2}{|c|}{$\begin{array}{l}\text { 11a. Modification Work } \\
{[] \text { Yes (fill out Blk. }} \\
\text { 11b) } \\
{[X] \text { No (NA Blks. 11b, }} \\
11 \mathrm{c}, 11 \mathrm{~d} \text { ) }\end{array}$}} & \multirow[t]{2}{*}{$\begin{array}{l}\text { 11b. Work Package } \\
\text { No. } \\
\text { N/A }\end{array}$} & \multicolumn{2}{|c|}{$\begin{array}{l}\text { 11c. Modification Work Complete } \\
\text { N/A }\end{array}$} & $\begin{array}{l}\text { 11d. Restored to original Condi- } \\
\text { tion (Temp. or Standby ECN on(y) } \\
N / A\end{array}$ \\
\hline & & & \multicolumn{2}{|c|}{ Cog. Engineer Signature \& Date } & Cog. Engineer Signature \& Date \\
\hline
\end{tabular}

12. Description of Change

Complete revision.

13a. Justification (mark one)

Criteria Change [X] Design Improvement [] Environmental [] Facility Deactivation [] As-Found [] Facilitate Const [] Const. Error/Omission [] Design Error/Omission []

13b. Justification Details

Changed to comply with new template and DOE-RL recommended modifications.

16. Distribution (include name, MSIN, and no. of copies)

See attached distribution. 
16. Cost Impact

Page 2 of 2

\begin{tabular}{|c|c|}
\hline $\begin{array}{l}\text { 15. Design } \\
\text { Verification } \\
\text { Required } \\
{[] \text { res }} \\
{[X] \text { No }}\end{array}$ & $\begin{array}{l}\text { 16. Cost } \\
\text { Addition } \\
\text { Savings }\end{array}$ \\
\hline \multicolumn{2}{|c|}{$\begin{array}{l}\text { 18. Change } 1 \text { mpact R } \\
\text { that will be af } \\
\text { SDD/DD }\end{array}$} \\
\hline \multicolumn{2}{|c|}{ Functional Design Criteria } \\
\hline \\
\hline \multicolumn{2}{|l|}{ Criticality Specification } \\
\hline \multicolumn{2}{|c|}{ Conceptual Design Report } \\
\hline \multicolumn{2}{|l|}{ Equipment Spec. } \\
\hline \multicolumn{2}{|l|}{ Const. Spec. } \\
\hline \multicolumn{2}{|l|}{ Procurement Spec. } \\
\hline \multicolumn{2}{|l|}{ Vendor Information } \\
\hline \multicolumn{2}{|l|}{ OM Manual } \\
\hline \multicolumn{2}{|l|}{ FSAR/SAR } \\
\hline \multicolumn{2}{|l|}{ Safety Equipment List } \\
\hline \multicolumn{2}{|l|}{ Radiation Work Permit } \\
\hline \multicolumn{2}{|c|}{ Environmental Impact Statement } \\
\hline \multicolumn{2}{|l|}{ Environmental Report } \\
\hline Environmental Permit & \\
\hline
\end{tabular}
19. Other Affected Documents: (MOTE: Documents (isted below will not be revised by this ECN.) Signatures below indicate that the signing organization has been notified of other affected documents listed below.

$N / A$

ENGINEERIMG

[] Yes

$\begin{array}{ll}{[]} & \$ \\ {[]} & \$\end{array}$

CONSTRUCTION

ECN-631558

8. Change Impact Review: Indicate the related documents (other than thi: engineering documents ident ified on side 1) that will be affected by the change described in Block 12 . Enter the affected document number in 81 ock 19.

[] Stress/Design Report

[] Interface Control Drawing

[] Calibration Procedure

[] Installation Procedure

[] Maintenance Procedure

[] Engineering Procedure

[] Operating Instruction

[] Operating Procedure

[] Operational Safety Requirement

[] IEFD Drawing

[] Cell Arrangement Drawing

[] Essential Material Specification

[] Fac. Proc. Samp. Schedule

[] Inspection Plan

[] Inventory Adjustment Request
[]

[]

[]

[]

[]

[]

[]

[]

[]

[]

[] Process Flow Chart

[] Purchase Requisition

[] Tickler File

[]

Tank Calibration Manual

Health Physics Procedure

Component Index

ASME Coded Item

Computer Software

Electric Circuit Schedule

ICRS Procedure

Filo

Spares Multiple Unit listing

Test Procedures/Specification

Human Factor Consideration

\section{Approvals}

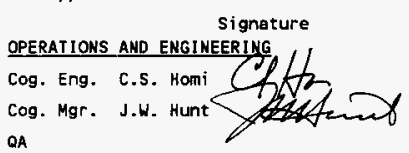

Safety

Environ.

other L.L. Bucktey Polf.

\begin{tabular}{|c|c|c|}
\hline Date & $\begin{array}{l}\text { Signature } \\
\text { ARCHITECT-ENGINEER }\end{array}$ & Date \\
\hline $5 / 9 / 92$ & PE & \\
\hline $574 / 96$ & QA & \\
\hline & Sefety & \\
\hline & Design & \\
\hline & Environ. & \\
\hline $5 / 9196$ & Other & \\
\hline & DEPARTMENT OF EMERGY & \\
\hline & $\begin{array}{l}\text { Signature or a Control Number that } \\
\text { tracks the Approval Signature }\end{array}$ & \\
\hline & ADDITIONAL & \\
\hline & & \\
\hline
\end{tabular}




\title{
Tank 241-S-110 Tank Characterization Plan
}

\author{
C. S. Homi
}

Westinghouse Hanford Company. Richland, WA 99352

U.S. Department of Energy Contract DE-AC06-87RL10930

EDT/ECN: $\quad$ ECN-631558 UC: 2070

Org Code: 79200 Charge Code: N4G6A

B\&R Code: EW 3120074 Total Pages: 10

Key Words: Characterization. General Safety Issues. Specific Safety Issues, Information Requirements, Schedule

Abstract: This document is a plan that identifies the information needed to address relevant issues concerning short-term and long-term storage and long-term management of single-shel1 tank 241-S-110.

TRADEMARK DISCLAIMER. Reference herein to any specific commercial product, process, or service by trade name, trademark, manufacturer, or otherwise, does not necessarily constitute or imply its endorsement, recommendation, or favoring by the United States Government or any agency thereof or its contractors or subcontractors.

Printed in the United States of America. To obtain copies of this document, contact: WHC/8CS Document Control Services, P.O. Box 1970, Mailstop H6-08, Richland WA 99352, Phone (509) 372-2420. Fax (509) 376-4989.
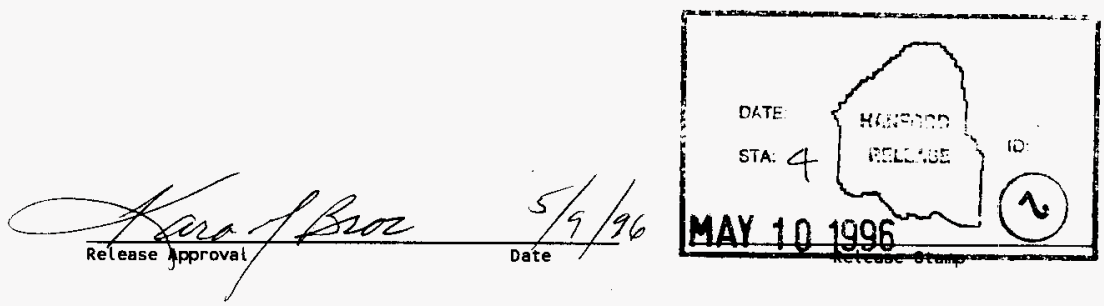

\section{Approved for Public Release}


(2) Title

TANK 241-S-110 TANK CHARACTERIZATION PLAN

CHANGE CONTROL RECORD

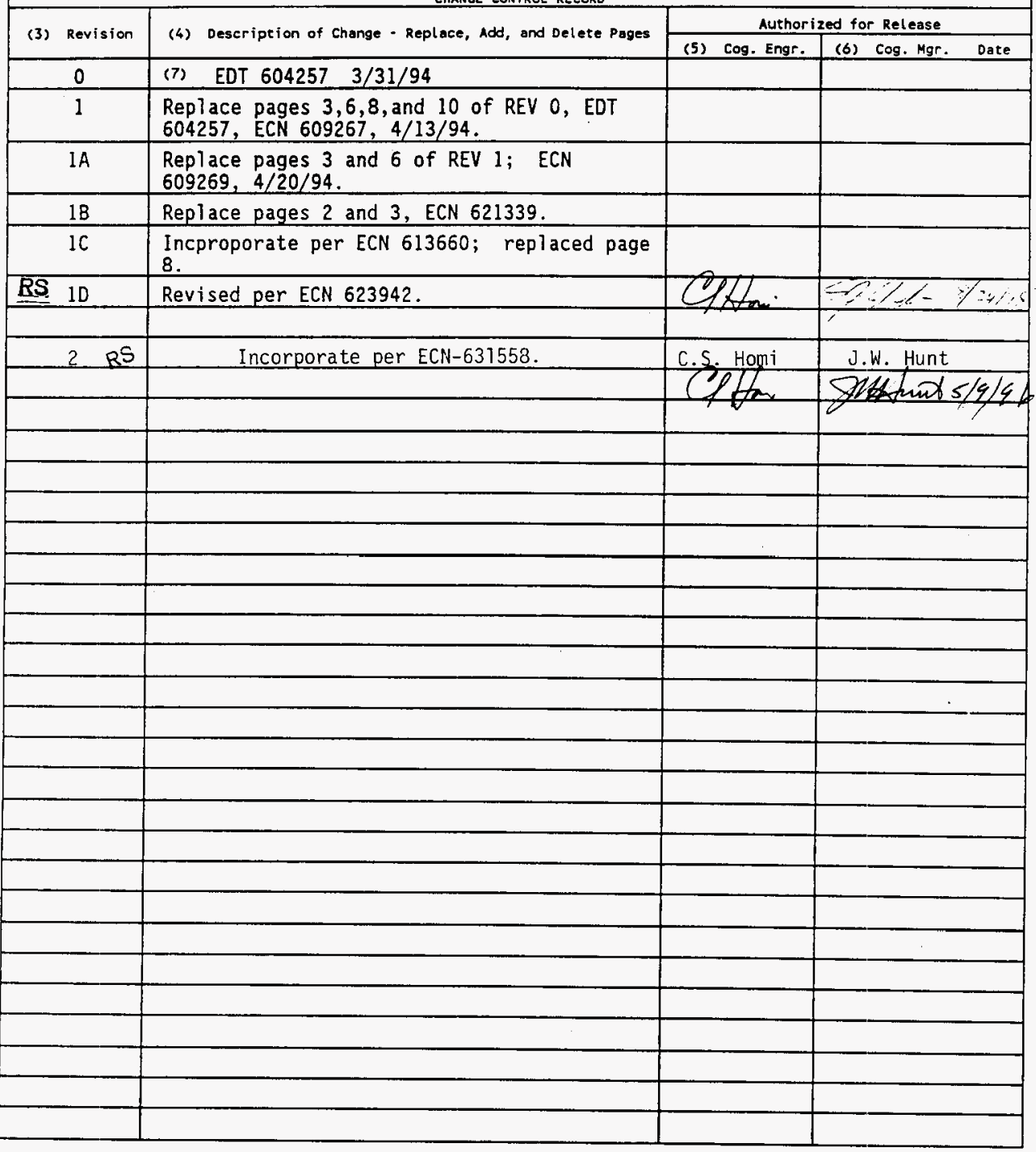


WHC-SD-WM-TP-205

Revision 2

UC-2070

Tank 241-S-110

Tank Characterization Plan

L. L. Buckley

Westinghouse Hanford Company

Date Published

May 1996
Prepared for the U.S. Department of Energy Office of Environmental Restoration and Waste Management
P.O. Box 1970

Richland, Washington

Management and Operations Contractor for the

U.S. Depsrtment of Energy under Contract DE-AC06-87RL10930

Approved for Public Release 
WHC-SD-WM-TP-205 REV 2

TABLE OF CONTENTS

1.0 INTRODUCTION . . . . . . . . . . . . . . . . . . . . . 1

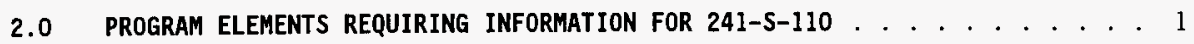

2.1 GENERAL SAFETY ISSUES ...................... . . 1

2.2 SPECIFIC SAFETY ISSUES . . . . . . . . . . . . . . 2

2.2 .1 Ferrocyanide ................. 2

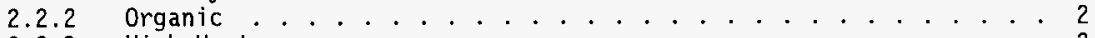

2.2 .3 High Heat .................. 2

2.2.4 Flammable Gas ................ 2

2.2 .5 Vapor ................. 2

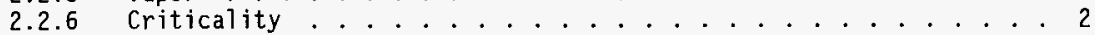

2.3 CONTINUING OPERATIONS . . . . . . . . . . . . . . . 2

2.3.1 Compatibility/Stabilization .............. 2

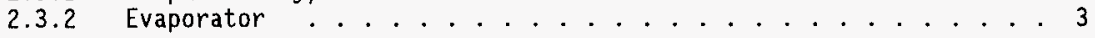

2.4 DOUBLE-SHELL TANK WASTE ANALYSIS PLAN ............. 3

2.5 DISPOSAL . . . . . . . . . . . . . . . . . . 3

2.5.1 Retrieval ............. . . 3

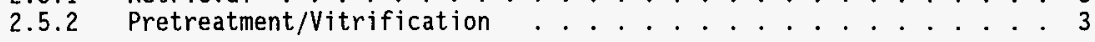

2.6 HISTORICAL MODEL EVALUATION . . . . . . . . . . . . . . 3

3.0 HOW INFORMATION WILL BE OBTAINED ............... 3

4.0 PRIORITY OF INFORMATION REQUIREMENTS .................. . . . 4

5.0 WHEN INFORMATION WILL BE AVAILABLE .............. 4

6.0 REFERENCES ........................ . 4

\section{LIST OF TABLES}

Table 4-1: Integrated DQO Requirements and Priorities........... 4 


\subsection{INTRODUCTION}

This Tank Characterization Plan (TCP) identifies the information needed to address relevant issues concerning short-term and long-term safe storage and long-term management of single-shell tank 241-S-110 (S-110). It should be understood that the various needs and issues surrounding tank $5-110$ are evolving as new information about the tank is uncovered. As a result of this progression, this TCP addresses only the issues that, to this date, have been identified. It is expected that deviations from this plan may occur as additional issues or needs arise which impact the management of tank S-110. This TCP will be revised as necessary to reflect those changes or deviations. This plan reflects the best information available as of May 1996.

Tank S-110 was constructed between 1950 and 1951 and was put into service in 1952 . Initially tank S-110 received waste from the Reduction 0xidation (REDOX) facility from the second quarter of 1952 until the fourth quarter of 1973 . During the third and fourth quarters of 1953 the tank also received REDOX cladding waste. From the first quarter of 1954 until the third quarter of 1974, the tank received wastewater. From the first quarter of 1974 until the first quarter of 1978, the tank was filled with various wastes from BX, S, SX, T, TX and U Tank Farms and the 242-S Evaporator. The tank received partial neutralized feed waste from the second quarter of 1978 unt il the third quarter of 1980. The tank contains non-complexed waste, is sound, and is passively ventilated. It was removed from service and labeled inactive in 1976 (Brevick et al. 1995).

Tank S-110 currently contains waste with a total volume of $1,476 \mathrm{~kL}$ ( $390 \mathrm{kgal})$, which is equivalent to $379 \mathrm{~cm}$ (149 in) of waste as measured from the baseline of the tank.

Tank S-110 is not on any Watch List.

Near-term sampling and analysis activities are focused on either verifying or changing the Watch List tank status, and identifying any new safety issues. Should any safety issues be identified, additional analysis will occur consistent with the identified issue.

In addition to the resolution of the safety issues, it is intended that all tank waste will be subject to pretreatment and retrieval to prepare for final storage or disposal. Presently these long-range plans have yet to be fully identified and are, therefore, not included in this document.

\subsection{PROGRAM ELEMENTS REQUIRING INFORMATION FOR TANK 241-S-110}

This section identifies the various program elements, and identifies which of these programs require characterization data from tank $5-110$.

\subsection{GENERAL SAFETY ISSUES}

The Tank Safety Screening Data Quality Objective (Dukelow et a1. 1995) describes the sampling and analytical requirements that are used to screen waste tanks for unidentified safety issues. Analytical requirements for the safety screening of a tank are energetics, total alpha activity, moisture content, density, and flammable gas concentration. 


\subsection{SPECIFIC SAFETY ISSUES}

\subsubsection{Ferrocyanide}

This tank is not on the Ferrocyanide Watch List; therefore, no information needs are currently identified for this program element.

\subsubsection{Organic}

This tank is not on the Organic watch List; therefore, no information needs are currently identified for this program element.

\subsubsection{High Heat}

This tank is not on the High Heat watch List; therefore, no information needs are currently identified for this program element.

\subsubsection{Flammable Gas}

This tank is not on the Flammable Gas Watch List; therefore, no information needs are currently identified for this program element.

\subsubsection{Vapor}

A11 177 underground tanks must be vapor-sampled for organic solvent screening as per Recommendation 93-5 Implementation Plan (DOE-RL 1996). Some tanks may require additional vapor sampling due to other program needs. These tanks may be classified into four categories: (1) those tanks which are to be rotary mode core sampled (as a consequence of the rotary sampling system exhauster permit requirements); (2) tanks on the Organic or Ferrocyanide Watch Lists; (3) tanks in C farm; and (4) tank 241-BX-104, due to vapor exposure. Information needs must satisfy Data Quality objectives for Tank Hazardous Vapor Safety Screening (Osborne and Buckley 1995), and for rotary mode only, Rotary Core Vapor Sampling Data Quality Objective (Price 1994), and Data Quality Objective for Regulatory Requirements for Hazardous and Radioactive Air Emissions Sampling and Analysis (Mulkey and Markillie 1995) as amended by Status of the Current Understanding of the Toxic Air Pollutants (TAPS) and Hanford Tank Farm Vapor Space Characterization; Recommended Path Forward and Justification for Continued RMCS Exhauster Operations (Laws 1996).

Tank S-110 was vapor sampled in December 1995 in support of Osborne et al. (1994).

\subsubsection{Criticality}

No information separate from that for the general safety issue of tank S-110 are currently identified for this program element. However, if the general safety screening of tank S-110 identifies a potential criticality concern, analyses for fissile materials and neutron sorbers and poisons will be performed as identified in the safety screening data quality objective (DQ0).

\subsection{CONTINUING OPERATIONS}

\subsubsection{Compatibility/Stabilization}

Tank S-110 waste will be sampled to determine compatibility. Sampling and analysis requirements must be performed as per Data Quality objectives for the Waste 
Compatibility Program (Fowler 1995). The analyses employed will be used to quantify transuranics such as ${ }^{230} \mathrm{Pu}$ and ${ }^{241} \mathrm{Am}$, Total Organic Content (TOC), and heat generation (as determined by the amount of ${ }^{90} \mathrm{Sr}$ and ${ }^{137} \mathrm{Cs}$.

\subsubsection{Evaporator}

This section does not apply to tank S-110.

\subsection{DOUBLE-SHELL TANK WASTE ANALYSIS PLAN}

This section does not apply because tank $\mathrm{S}-110$ is a single shell tank.

\subsection{DISPOSAL}

\subsubsection{Retrieval}

Current retrieval needs (Bloom 1995) do not call for test samples to be taken from tank $S-110$.

\subsubsection{Pretreatment/Vitrification}

Tank S-110 has been identified as a bounding tank for pretreatment/disposal process development strategy (Kupfer el al. 1995). The strategy only requires that sample material be made available via archive samples and does not require any specific analyses to be done on the samples.

\subsection{HISTORICAL MODEL EVALUATION}

Bounding tanks and data requirements for historical model evaluations are found in DQO Historical Model Evaluation Data Requirements (Simpson et al. 1995). Tank S-110 has been identified as a primary bounding tank for high level REDOX waste and saltcake waste types. All single-shell tanks were prioritized in the Tank Waste Characterization Basis (Brown et al. 1995) document using the Historical DQO .

\subsection{HOW INFORMATION WILL BE OBTAINED}

The number of samples required to characterize a tank is a function of waste heterogeneity and the desired confidence to make a correct decision. As directed by the safety screening $\mathrm{DQO}$, if inadequate information exists to determine an appropriate number of samples, two vertical profiles will be obtained. These vertical profiles may be obtained using core, auger (for shallow tanks), or grab samples. If analysis of these profiles reveals that additional profiles are necessary to meet data needs, more sample profiles will be requested. Prior to rotary sampling it is necessary to vapor sample the tank per the requirements of Rotary Core Vapor Sampling Data Quality objective (Price 1994). 


\subsection{PRIORITY OF INFORMATION REQUIREMENTS}

Vapor sampling was completed in December 1995. Grab sampling was completed in March 1996. Rotary mode core sampling was scheduled to begin in March 1996 but has been delayed for operational reasons (Stanton 1996). Refer to Table 4.l for the current DQO requirements and planned sampling and analytical requirements.

Table 4-1: Integrated DQO Requirements and Priorities

\begin{tabular}{||l|l|l|l||}
\hline $\begin{array}{l}\text { Sampling } \\
\text { Event }\end{array}$ & Applicable Issues & Sampling Requirements & \multicolumn{1}{|c||}{$\begin{array}{c}\text { Analytical } \\
\text { Requirements }\end{array}$} \\
\hline $\begin{array}{l}\text { Vapor } \\
\text { Sampling }\end{array}$ & $\begin{array}{l}\text {-Organic Solvent Layer } \\
\text { 93-5 Vapor Issue } \\
\text {-Rotary Mode Sampling } \\
\text { DQO } \\
\text {-Hazardous Vapor DQ0 }\end{array}$ & $\begin{array}{l}\text { Steel canisters, } \\
\text { Triple Sorbent Traps, } \\
\text { Sorbent Trap Systems }\end{array}$ & $\begin{array}{l}\text { Flammable Gas } \\
\text { Organic Vapors } \\
\text { Permanent Gases }\end{array}$ \\
\hline $\begin{array}{l}\text { Rotary } \\
\text { Mode Core } \\
\text { Sampling }\end{array}$ & $\begin{array}{l}\text {-Safety Screening DQ0 } \\
\text {-Historical Model DQ0 }\end{array}$ & $\begin{array}{l}\text { Core samples from 2 } \\
\text { risers separated } \\
\text { radially to the maximum } \\
\text { extent possible } \\
\text { Combustible gas } \\
\text { measurement }\end{array}$ & $\begin{array}{l}\text { Flammability, } \\
\text { Energetics, Moisture, } \\
\text { Density, Anions, } \\
\text { Metals, Radionuclides, } \\
\text { Total Organic Carbon }\end{array}$ \\
\hline $\begin{array}{l}\text { Grab } \\
\text { Sampling }\end{array}$ & -Compatibility DQ0 & 3 grab samples. & $\begin{array}{l}\text { Energetics, Moisture, } \\
\text { Anions, Cations, } \\
\text { Radionuclides, Specific } \\
\text { gravity, pH, Separable } \\
\text { Organics, Total Organic } \\
\text { Carbon, Total Inorganic } \\
\text { Carbon, Percent Solids }\end{array}$ \\
\hline
\end{tabular}

* Consult each applicable DQO in force at the time for sampling and analytical requirements.

\subsection{WHEN INFORMATION WILL BE AVAILABLE}

According to Stanton (1996) data are expected to be available from the grab sampling event for tank $\mathrm{S}-110$ in July 1996. Since rotary mode core sampling is not yet authorized, data can not be expected until approximately 105 days after sampling actually occurs. Data are available from the December 1995 vapor sampling.

\subsection{REFERENCES}

Bloom, G. R. and Q. H. Nguyen, 1995, Characterization Data Needs for Development, Design and Operation of Retrieval Equipment Developed Through the Data Quality Objective Process, WHC-SD-WM-DQ0-008, Rev. 0, Westinghouse Hanford Company, Richland, Washington.

Brevick, C. H., L. A. Gaddis, and W. W. Pickett, 1995, Historical Tank Content Estimate for the Southwest Quadrant of the Hanford 200 East Areas, WHC-SD-WM-ER-352, Rev. OA, Westinghouse Hanford Company, Richland, Washington. 
Brown, T. M., S. J. Eberlein, and T. J. Kunthara, 1995, Tank Waste Characterization Basis, WHC-SD-WM-TA-164, Rev. 1, Westinghouse Hanford Company, Richl and, Washington.

D0E-RL, 1996, Recommendation 93-5 Implementation P7an, D0E/RL-94-0001, Rev. 1, U.S. Department of Energy, Richland, Washington.

Dukelow, G. T., J.W. Hunt, H. Babad, and J. E. Meacham, 1995, Tank Safety Screening Data Quality Objective, WHC-SD-WM-SP-004, Rev. 2, Westinghouse Hanford Company, Richland, Washington.

Fowler, K. D. 1995, Data Quality Objectives for Tank Farm Waste Compatibility Program, WHC-SD-WM-DQ0-001, Rev. 1, Westinghouse Hanford Company, Richland, Washington.

Hanlon, B.M., 1996, Waste Tank Summary for Month Ending January 31, 1996, WHC-EP-0182-94, Westinghouse Hanford Company, Richland, Washington.

Kupfer, M. J., W. W. Schultz, and J. T. Slankas, 1995, Strategy for Sampling Hanford Site Tank Wastes for Development of Disposal Technology, WHC-SD-WM-TA-154, Rev.

1, Westinghouse Hanford Company, Richland, Washington.

Laws, G. L., 1996, Status of the Current Understanding of the Toxic Air Pollutants (TAPS) and Hanford Tank Farm Vapor Space Characterization; Recommended Path Forward and Justification for Continued RMCS Exhauster Operations, (telephone conference memorandum, 01830-96-022, to Distribution, March 8) Westinghouse Hanford Company, Richland, Washington

Mulkey, C. H. K. D. Markillie, 1995, Data Quality Objective for Regulatory Requirements for Hazardous And Radioactive Air Emissions Sampling and Analysis, WHCSD-WM-DQ0-021, Rev. 0, Westinghouse Hanford Company, Richland, Washington

Osborne, J. W., L. L. Buckley, 1995, Data Quality Objectives for Tank Hazardous Vapor Safety screening, WHC-SD-WM-DQO-002, Rev. 2, Westinghouse Hanford, Richland, Washington.

Osborne, J. W., J. L. Huckaby, E. R. Hewitt, C. M. Anderson, D. D. Mahlum, B. A. Pulsipher, and J. Y. Young, 1995, Data Quality Objectives for Generic In-Tank Hea7th and Safety Vapor Issue Resolution, WHC-SD-WM-DQ0-002, Rev. 0, Westinghouse Hanford, Richland, Washington.

Price, D. N. 1994, Rotary Core Vapor Sampling Data Quality Objective, WHC-SD-WM-SP-003, Rev. 0, Westinghouse Hanford Company, Richland, Washington.

Simpson, B. C., D. J. McCain, 1995, Historical Model Evaluation Data Requirements, WHC-SD-WM-DQ0-018, Rev. 0, Westinghouse Hanford Company, Richland, Washington.

Stanton, G. A., 1996, Baseline Sampling Schedu7e, Change 96-02, (internal memo 75610-96-06, to Distribution, April 17), Westinghouse Hanford Company, Richland, Washington. 


\begin{tabular}{|c|c|c|c|c|c|}
\hline \multicolumn{6}{|c|}{ DISTRIBUTION SHEET } \\
\hline \multirow{2}{*}{$\begin{array}{l}\text { To } \\
\text { Distribution }\end{array}$} & \multirow{2}{*}{\multicolumn{3}{|c|}{$\begin{array}{l}\text { From } \\
\text { Evaluation and Planning }\end{array}$}} & \multicolumn{2}{|l|}{ Page 1 of 1} \\
\hline & & & & \multicolumn{2}{|c|}{ Date $\quad 05 / 09 / 96$} \\
\hline \multicolumn{4}{|l|}{ Project Title $/$ Work Order } & \multicolumn{2}{|c|}{ EDT No. $\quad \mathrm{N} / \mathrm{A}$} \\
\hline \multicolumn{4}{|c|}{$\begin{array}{l}\text { WHC-SD-WM-TP-205, Rev. 2, "Tank 241-S-110 Tank Characterization } \\
\text { Plan" }\end{array}$} & \multicolumn{2}{|c|}{ ECN No. $\quad E C N-631558$} \\
\hline Name & MSIN & $\begin{array}{c}\text { Text } \\
\text { With } \\
\text { A17 } \\
\text { Attach. }\end{array}$ & Text Only & $\begin{array}{l}\text { Attach, / } \\
\text { Appendix } \\
\text { Only }\end{array}$ & $\begin{array}{l}\text { EDT/ECN } \\
\text { Only }\end{array}$ \\
\hline
\end{tabular}

ONSITE

U. S. Department of Energy -

Richland Field office

W. Liou

N. W. Willis

$\begin{array}{ll}57-54 & x \\ 57-54 & x\end{array}$

Westinghouse Hanford Company

L. L. Buck Tey

G. D. Forehand

C. S. Homi

Central Files

T.C.R.C.

R2-12

S7 -21

$\mathrm{R} 2-12$

A3- 88

$\mathrm{R} 2-12$

$x$
$x$
$x$
$x$
$x$

\section{DFFSITE}

U. S. Department of Energy - Headquarters

Office of Environmental Restoration and Waste Management EM-563

12800 Middlebrook Road

Germantown. MD 20874

J. A. Poppiti

$x$ 